\title{
当教室15年間の下気道・食道異物の統計的観察
}

\author{
上田 隆志・衞藤 幸男・柏木 令子 \\ 太田 和博・田中 治・松永喬
}

\section{A Review of Cases of Tracheo-Bronchial and Esophageal Foreign Bodies Treated during the Past Fifteen Years}

\author{
Takashi Ueda, Yukio Eto, Noriko Kashiwagi, Kazuhiro Ohta, \\ Osamu Tanaka and Takashi Matsunaga \\ (Nara Medical University)
}

\begin{abstract}
A statistical study was made on the cases of the foreign bodies in the tracheo-bronchus and esophagus treated in our clinic between 1972 and 1986.

Thirty cases in the tracheo-bronchus, (male to female ratio was 2 to 1 ), were treated. The annual incidence was not remarkably changed. About 85 percent of the total cases were below age 10 , especially 43 percent were one-years-old babies. Beans as the foreign bodies were most, 50 percent. The difference in the incidence between the right bronchus and left was not observed.

There were 256 cases in the esophagus with a sex ratio of 1 to 1 were found. The incidence had no remarkable change. Two peaks were observed in the age distribution, the one in children below age 10 and the other in aged people above 60 . About 45 percent of foreign bodies were coins, 14 percent fish bone and 11 percent pieces of meat. Almost coins observed in the cases of children and pieces of meat were found frequently in the aged. The incidence of PTP foreign bodies appeared to be increasing.
\end{abstract}

Key words: tracheo-bronchial foreign bodies, esophageal foreign bodies, statistical study

\author{
はじめに \\ 今回我々は，当科に扐ける15年間の下気道お \\ よび食道異物の臨床統計的観察を行ったので報 \\ 告する.
}

\section{対象と方法}

昭和 47 年から昭和 61 年までの15年間に当科に おいて，下気道，食道に異物の存在を確認した 症例を対象とした。下気道異物としては，気管 および気管支に介在するものを対象とした。こ の期間の下気道異物症例は30例で，年踰分布は
9 ケ月より 65 歳, 平均 8.0 歳であった. また食 道異物症例は256例で，年齢分布は 4 ケ月より 83歳, 平均29.5歳であった. 調査項目は, 15年 間の年次推移, 性比, 年路分布, 異物の種類, 摘出方法抌よ゙合併症である。

\section{統計結果}

\section{1. 一般統計}

調査期間の15年間に当科外来を受診した疑い 例を含む全異物症例数は2831例で，この期間の 当科の外来患者総数の約 $0.72 \%$ 占めた. 内訳 
は表1のと拈りである.2831例のうち主訴・症 状などより下気道異物を疑われた症例は54例 （1.9\%）で，異物を確認した30例はさらにその らちの $55.6 \%$ にあたった。 また食道異物を疑わ れた症例は702例 $(24.8 \%)$ で, 確認例256例は そのらちの36.5\%にあたった。

\section{2. 下気道異物}

1) 年次推移

下気道異物の症例数の年次推移には増加や減 少の傾向はみられず，毎年注ぼ $2 ， 3$ 例が認め られた（図 1 ).

2）性 比

性別症例数を比較すると, 男性 20 例, 女性 10 例で, 性比 2：1 と従来から報告されていた1)-15) と拈り，男性に多い傾向がみられた（図 2）。

表 1 異物の部位別頻度

\begin{tabular}{|c|c|c|c|}
\hline 部 & 位 & 例 数 & 頻度（\%) \\
\hline 外 & 耳 道 & 487 & 17.2 \\
\hline 鼻 & 腔 & 495 & 17. 5 \\
\hline 口腔 & - 咽頭 & 854 & 30.2 \\
\hline 食 & 道 & 702 & 24.8 \\
\hline 胃 & 腸 & 173 & 6.1 \\
\hline 下 & 気 道 & 54 & 1.9 \\
\hline 喉 & 頭 & 54 & 1.9 \\
\hline & の 他 & 12 & 0.4 \\
\hline & & 2,831 & \\
\hline
\end{tabular}

(単位 : 例)

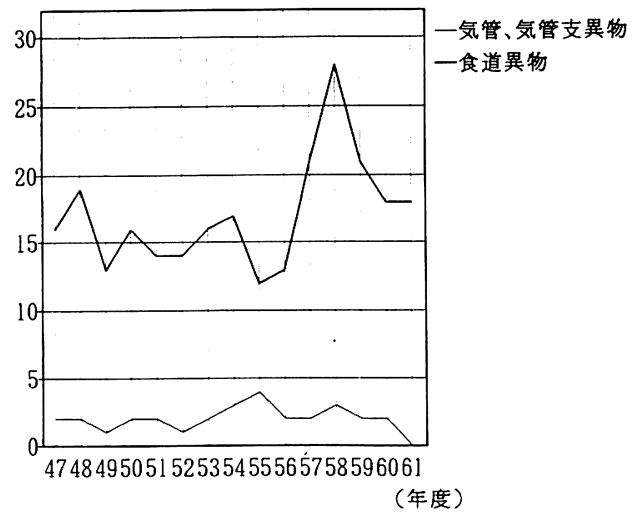

図 1 異物症例の年次推移
3）年齢分布

年齢分布を図 3 に示した。10歳未満が26例 （86.6\%）と大多数を占め, 中でも 1 歳代に 13 例（43.3\%）と集中していた．20歳以上の成人 例は 2 例のみであった。

4）異物の種類

異物の種類は，ピーナッッが15例（50.0\%） と半数を占めた。 ピーナッツを含め 22 例（73.3 \%）が食物による異物であった．成人例の 2 例 は，いずれも義歯による異物であった．X線非 透過性の異物は 4 例 (13.3\%) のみで, 残りの 26 例（86.7\%）は透過性であった（表 2 ）.

5）介在部位

下気道異物の介在部位は，気管10例，右気管 支10例, 左気管支10例と部位差は認められなか った（表 3 ).

6）摘出方法および合併症

摘出は，全例全身麻醉下に硬性気管支鏡およ び ventilation bronchoscope を用いて行った。 摘出後の合併症は, 肺炎 2 例, 気管支炎 3 例の

下気道異物

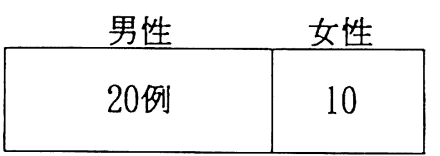

食道異物

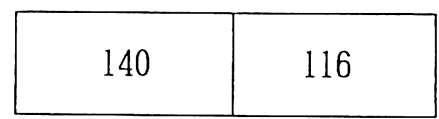

図 2 性別の異物症例数

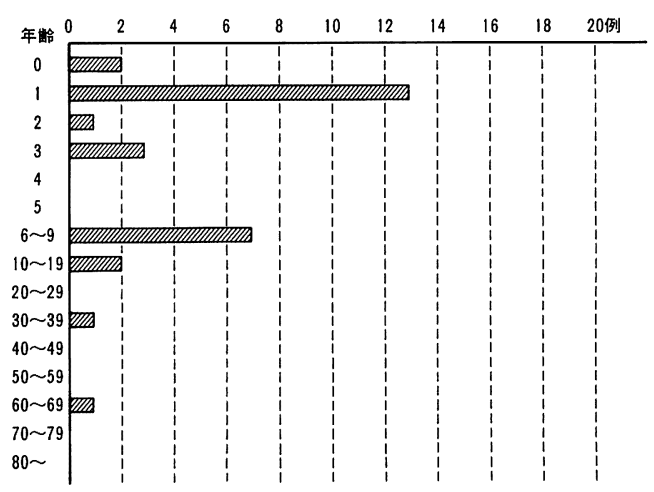

図 3 下気道異物の年蹂分布 
計 5 例 $16.7 \%$ にみられた。このらち死亡例の 1 例は, チョコボールによる異物の 1 歳 8 力月男 児で，摘出翌日，肺炎を合併し死亡した。

3. 食道異物

1）年次推移

食道異物256例の年次推移は図 1 のごとく, 当付属病院の改築のあった 57 年度以降わずかに 増加があるものの，毎年10２0例でほほぼ一定し ていた。

2）性 比

食道異物では，男性140例に対し女性116例で ほぼ性差はみられなかった（図３）。

3）年齢分布

食道異物でも 10 歳未満の症例が134例（52.2 \%) 之過半数であったが，下気道異物に比較す ると幅広い分布がみられた。また 70 歳代 31 例 (12.1\%)，60歳代28例（10.9\%）と，高齢者に も多く，2 峰性の分布が認められた（図 4).

表 2 下気道異物の種類およびX線透過性の有無 による頻度（昭和47～61年）

\begin{tabular}{|c|c|c|c|}
\hline & 類 & 例 & 数 \\
\hline $\begin{array}{l}X \\
\text { 透過線 } \\
\end{array}$ & 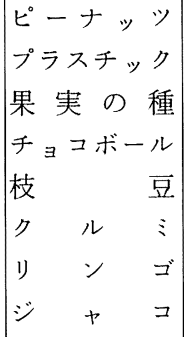 & $\begin{array}{cc}15 \text { 例 } & (50.0 \%) \\
4 & (13.3 \%) \\
2 & (6.6 \%) \\
1 & (3.3 \%) \\
1 & (3.3 \%) \\
1 & (3.3 \%) \\
1 & (3.3 \%) \\
1 & (3.3 \%)\end{array}$ & 26例 (86.7\%) \\
\hline $\begin{array}{l}X \text { 線 } \\
\text { 非透過性 }\end{array}$ & $\begin{array}{lll}\text { 義 } & & \text { 歯 } \\
\text { リ } & - & \text { マ } \\
\text { マ } & \text { チ } & \text { 針 }\end{array}$ & \begin{tabular}{|ll}
2 & $(6.6 \%)$ \\
1 & $(3.3 \%)$ \\
1 & $(3.3 \%)$
\end{tabular} & 4 例(13.3\%) \\
\hline 合 計 & & $30(100.0 \%)$ & 30 例 (100.0\%) \\
\hline
\end{tabular}

表 3 下気道異物の介在部位 (昭和 $47 \sim 61$ 年)

\begin{tabular}{|c|c|c|c|}
\hline 気 & & 管 & 10 例 (33.3\%) \\
\hline 右 & 気 管 & 支 & 10 例 (33.3\%) \\
\hline 左 & 気 管 & 支 & 10 例 (33.3\%) \\
\hline & & + & 30例 \\
\hline
\end{tabular}

\section{4）異物の種類}

異物の種類は，貨幣による異物が 116 例 (45.3\%) と最多で，次いで魚骨36例（14.1\%), 肉類 29 例 $(11.3 \%)$, PTP (Press-ThroughPack) 17例 $(6.6 \%)$ ，義歯14例 $(5.5 \%)$ の順 に多くみられた（図 5 )。主な食道異物の種類 につき，年齢別発生頻度をみた。貨幣は幼少児 がほとんどで，10歳未満の症例が (96.6\%)を 占めた。肉類は70歳代に最も多くみられ，高齢 者に多い傾向があった。 またPTP 異物はそれ よりはやや若年者が中心であるが，50歳代以降 に多くみられた（表 4 ）。

5）介在部位

異物の介在部位は，第 1 狭窄部162例（63.3

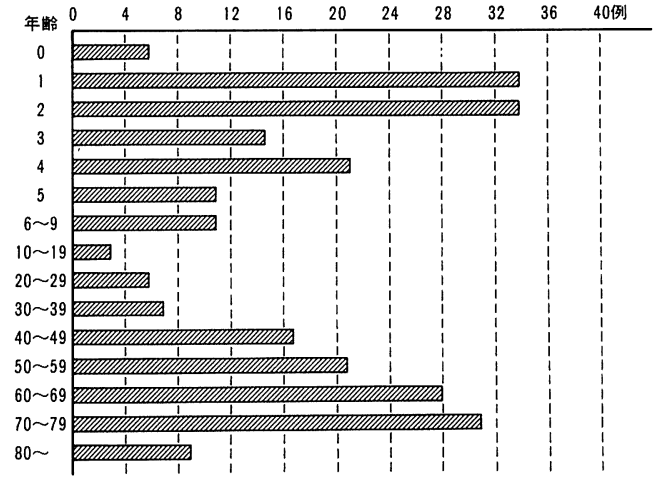

図 4 食道異物の年齡分布

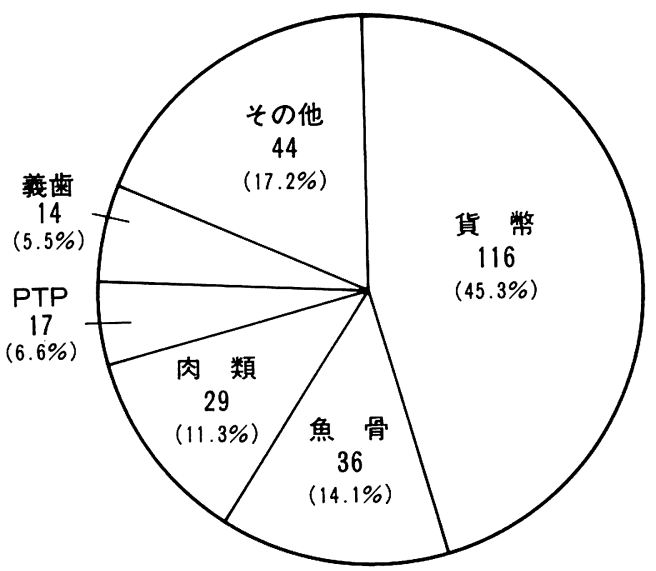

図 5 食道異物の種類と頻度 
$\%)$ ，第 2 狭窄部46例（18.0\%），第 3 狭窄部19 例 (7.4\%) で，第一狭窄部位が最も多かった (表 5 ).

\section{6）摘出方法打よび合併症}

食道外切開を必要としたもの 5 例, 胃内に落 下させたもの 3 例, 局所麻酔下に軟性の fiberscope で摘出したもの 3 例で, その他は全 身麻酔下に硬性食道直達鏡を用いて摘出した。 外切開を必要とした 5 例のらち 4 例は義歯で, も5 1 例は生節の骨であった。合併症は比較的 少なく, 鯛の骨を摘出後前頸部に皮下気腫を生 じた 1 例があった。

\section{考察}

\section{1. 一般統計}

異物の部位別頻度には報告によりかなりの差 が見られる. 大阪大学の昭和 7 年から昭和 57 年 までの統計では，食道56\%，口腔・咽頭 $15 \%$,

表 4 主な食道異物の年龄別発生頻度 (昭和 $47 \sim 61$ 年)

\begin{tabular}{c|c|c|c|c|c}
\hline \hline 年 齢 & 貨幣 & 義 歯 & 魚 骨 & 肉 類 & PTP \\
\hline $0 \sim 9$ 歳 & 112 例 & & & & 1 例 \\
$10 \sim 19$ & 2 & & & & \\
$20 \sim 29$ & & 2 例 & 2 例 & & \\
$30 \sim 39$ & 1 & 2 & 2 & 1 例 & \\
$40 \sim 49$ & & 4 & 8 & 2 & 2 \\
$50 \sim 59$ & 1 & 1 & 8 & 3 & 5 \\
$60 \sim 69$ & & 3 & 7 & 7 & 5 \\
$70 \sim 79$ & & 1 & 7 & 12 & 4 \\
$80 \sim$ & & 1 & 2 & 4 & \\
\hline 合 計 & 116 例 & 14 例 & 36 例 & 29 例 & 17例
\end{tabular}

表 5 食道異物の介在部位（昭和 $47 \sim 61$ 年）

\begin{tabular}{c|cr}
\hline \hline 第 1 狭窄部 & 162 例 & $(63.3 \%)$ \\
第 $1 \sim 2$ 狭窄部間 & 9 & $(3.5 \%)$ \\
第 2 狭窄部 & 46 & $(18.0 \%)$ \\
第 $2 \sim 3$ 狭窄部間 & 9 & $(3.5 \%)$ \\
第 3 狭窄部 & 19 & $(7.4 \%)$ \\
不 明 & 11 & $(4.3 \%)$ \\
\hline 合 計 & 256 例 & $(100.0 \%)$
\end{tabular}

胃腸 $10 \%$, 気道 $8 \%$, 鼻・副鼻腔 $6 \%$, 外耳 5 \%となっている5)。 また西浦10)によると昭和 44 年から昭和 55 年末でに扣いて，外耳 $45 \%$, 鼻腔 $14 \%$, 口腔 - 咽頭 $35 \%$, 食道 $4 \%$, 気道 $4 \%$ と なって拈り，大阪大学に比べると食道異物が少 なく外耳・鼻腔・腔咽頭の異物が多い.この 差は, 主として大学病院・開業医といら施設の 性質によるものと考学られる。我々の統計では 両者の中間的な結果であったが，大学病院であ りながら 1 次救急も取り扱い，また地域的な医 療を担ら役割をもっている当科の特殊な性格が 反映している思われる。

\section{2. 下気道異物}

下気道に拈ける異物は, 場合によっては致死 的であるため，その重要性は我々耳鼻科医は十 分認識しているにもかかわらず，症例の減少は みられないのが現状である。

年齡分布をみると，従来より報告されている ように圧倒的に小児多く1) 15), 特に 1 歳代に 集中していた。 また異物の種類では，ピーナッ ツを含めて, 食物, 中でも小さくて堅い食物に よる異物が大多数を占めており，食物以外のも のは少なかった。すなわち, 下気道異物の大半 が，咀嚼，嚥下機能や，咳嗽反射の発達が未熟 な小児に，異物となり易い食物を近づけこと が誘因となって発生しているのがわかる。一方， 貨幣などが食道異物として危険である事はよく 知られているのに対し，ピーナッツなどが下気 道異物の原因となることを十分に理解している 母親は少ない(13). したがって, 保護者, 主とし て母親に対し，たと食物であっても，小さく て堅いものは小児にとっては危険なのだといら ことを徹底的に教育することによって，下気道 異物を減少させることが可能ではないかと考え る. 地域医療の中心としての役割をもつ当科に とって，今後はこういった啓蒙活動もひとつの 重要な使命であると思われる15).

下気道異物の問題点のひとつに，X線透過性 異物が多いため, 診断が困難である点があげら れる. 我々の結果でも， $86.7 \%$ は透過性であっ 
た。田中ら 16) が報告しているよらに，十分な 問診, 理学的検査に加党, 単純X線撮影, 断層 撮影, RI シンチ, CT スキャンを適宜組み合 わせて, 慎重にかつすみやかに診断を行うこと が必要である（図 6 ）.

従来介在部位については，右側に多いという 報告が多く，気管支の直径，気管軸と気管支の なす角度, carina の位置等の理由で説明されて きた。しかし，気道に括ける異物は呼吸によっ て気管，左右の気管支の間を移動する場合があ り，また乳幼児では必ずしも右側に多いとは言 えないといら指摘や，むしろ左側に多かったと する報告も散見し17)，いずれとも確定しがたい． 我々の統計でも部位差は認められず，少なくと も診断や治療に際して右側優位にとられるべき ではないと思われた。

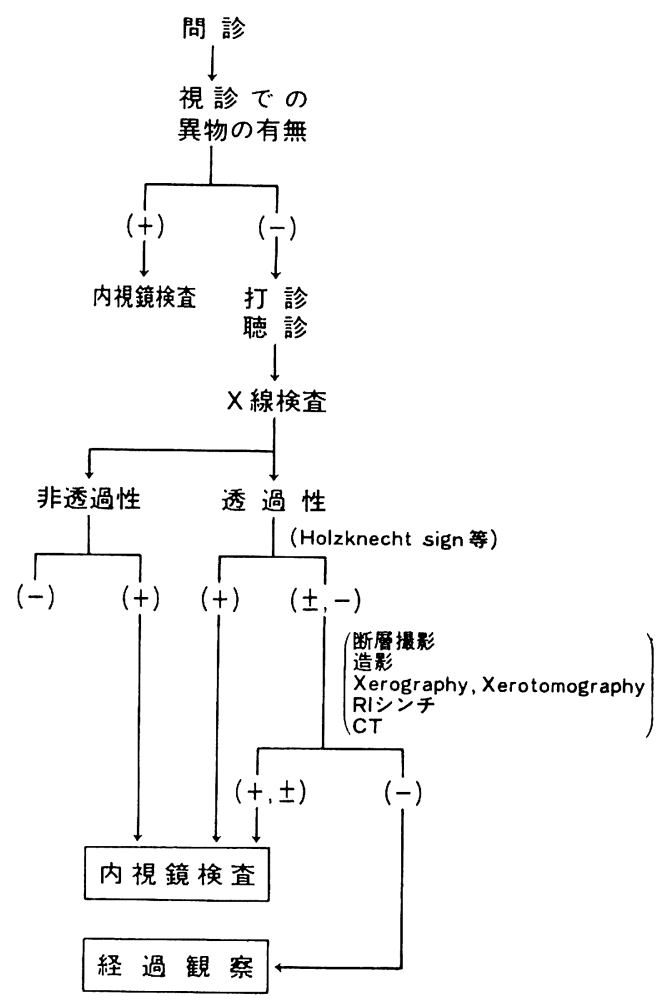

$(+)$ : 所見あり $( \pm)$ : 疑おしい $(-)$ : 所見なし

図 6 気道異物の診断手順 ventilation bronchoscope により, 全身麻酔 下での摘出の安全性が高まり, 当科でも器具が 導入されて以降は全例これを用いている.

軟性の fiberscope により摘出された例はな かったが, 最近は軟性の ventilation bronchofiberscope も開発されて拈り今後は使用される 機会が増して来るものと思われる.

\section{3. 食道異物}

食道異物では, 発症年齢は 1 歳, 2 歳を中心 とする小児と，70歳代，60歳代を中心とする高 齢者での 2 峰性の分布が見られた。また小児の 場合， 5 歳頃まで多くの症例がみられ，下気道 異物に比しょり広い年齢分布がみられた。

異物の種類は，従来より報告されているよ 54) 14)18) 飞貨幣, 魚骨, 肉類が多くみられた が，PTP による異物が6. 6\%占めているのが 注目される.PTP 異物の年次推移をみると, 15 年間で前半に当たる昭和 54 年までの 8 年間に は 2 例のみであったが, 後半の 7 年間で15症例 がみられた（図 7 )。PTP は広く普及しており 医療の变化に伴、特に高齢者が薬剤を服用する 機会が多くなって，PTP による異物は今後も みられると思われるが，X線透過性で診断が困 難ならえ，辺縁が鋭利で粘膜損傷を起こし易い こともあり注意を要する。 小児に打いては，貨幣異物が多くみられるこ と, 比較的年長児でも多くみられることから，

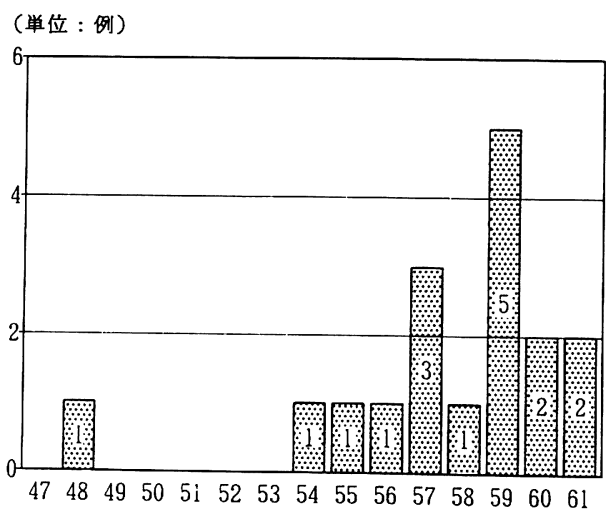

（年度）

図 7 PTP 異物の年次推移 
下気道異物の場合とは違い生理的機能とは無関 係に，本来口腔内に入れるべきでないものを入 れることによって, 異物が生じているのがわか る. この場合, 保護者は, それが危険であるこ とを十分にわかっているにもかかわらず生じて しまうわけであり，下気道異物より偶発的要素 が大きいと言える。また成人に执いて多くみら 机る PTP や義歯なども，やはり偶発的に異物 となる場合が多い，したがって予防には，日常 生活についての啓蒙とともに，すでに指摘され ているように貨幣の大きさ，PTP や義歯の材 料・形態などといった社会的な啓蒙が必要だと 考える19). 一方高齢者では, 肉類による異物が 多い事でもわかるように, 咀嚼, 嚥下機能, 唾 液分泌能などの衰えが，異物発生に影響してい るものと考えられる。

一般に食道では，第 1 狭窄部が最も狭いため， 異物もこの部位に介在する頻度が高い. 我々の 統計でも，第 1 狭窄部が， $63.3 \%$ と最多であっ た.しかし，異物の種類によって介在部位に多 少の差がみられ, 今回の調査では PTP 異物が 第 2 狭窄部にも 7 例 $41.2 \%$ と比較的多く又られ た。

摘出は，当科に拈いては全身麻酔下の硬性食 道直達鏡によるものがほとんどであった，近年 は軟性の fiberscope も発達し，これを用いた 局所麻酔下での摘出も行われている. 辺縁が鋭 利なものや, 軟性 fiberscope の鉗子では十分 の強さ・大きさでつかむことのできないもの， より広い視野での観察が必要なもの, 一回では 摘出し得ないものなど, 直達鏡の方が有利と思 われる症例が多いが，場合によってはより簡便 な局所麻酔下での軟性 fiberscope も有用であ ると思われる.

胃内に落下させた異物が 3 例あったが，特に 合併症はみられなかった。立木ら20) は胃内に 落下した異物 80 例中, 縫針の 2 例が自然排出せ ず腸壁を穿孔し手術の対象となり，また自然排 出した78例の排出日は翌日まで $32.1 \%$, 翌々日 まで53.8\%，5 日目までが87.2\%，7日目まで
92.3\%で，平均 3.4 日，最長31日であったと報 告している. 大部分は自然排出するが，特に鋭 利な異物は胃内に落下する前にすみやかに摘出 する必要がある。また一旦胃内に落下した場合 は，自然排出されるまで確実に，経過観察する べきだと考える。

食道外切開を必要とした異物のほとんどは義 歯で, 義歯床, ブリッジの形態が摘出を困難に していた，不適合で固定の悪い義歯は，定期的 に歯科医で改良してもらい，また就寝時には取 り外すよらに，日常診療に挴いて指導していく ことを心がけたい。

$$
\text { まとめ }
$$

当科における昭和 47 年から昭和 61 年までの 15 年間の下気道, 食道異物につき臨床統計観察を 行い, 以下の結果を得た.

1. 下気道異物を確認した症例は男性20例, 女性 10 例の計 30 例で, 年次に上る変化はみられ なかった。

2. 下気道異物の年齢分布では 10 歳未満が $86.6 \%$ 占め, 特に 1 歳代が $43.3 \%$ と多かった.

3. 下気道異物の種類ではピーナッツが50.0 \%で最も多かった。 また，異物の介在部位には 左右の気管支で差はみられなかった。

4. 食道異物症例は256例で, 注ぼ性差はな かった．年次による変化は認めなかった。

5. 食道異物の発生年齢には 10 歳未満の小児 と, 70 歳代, 60 歳代の高齢者での 2 峰性の分布 がみられた。

6. 食道異物の種類は貨幣, 魚骨, 肉類, 義 歯の順に多かったが，貨幣は小児に，肉類は高 齢者に多かった．最近はPTP も増加しており， 注意が必要と思われた。

7. 下気道異物・食道異物の予防には, 保護 者への啓蒙・社会的な啓蒙が重要だと思われる.

\section{文献}

1）牧清人, 安岡義人, 原田 紀, 他: 当教室 25 年間の気管・気管支異物の統計的観察. 耳鼻臨 床 $77: 666 \sim 671,1984$.

2）粟田口省吾, 宮野和夫, 袴田 勝: 気管・気管 
支異物63例の臨床的検討. 日気食会報 $31: 315$ $\sim 321,1980$.

3）代瓶誠五, 桶渡章二, 大八木章博, 他 : 当院に 拈ける気管気管支異物 10 年の統計観察之興味あ る若干例について。耳鼻臨床 $76: 753 \sim 763$, 1983.

4）松永 喬: 気道・食道異物症臨床の実際. 篠原 出版, 東京, 1983 .

5）鶴田至宏, 佐野光仁, 松永 喬: 当教室におけ る異物症の変遷. 日耳鼻 $87: 1527 \sim 1537,1984$.

6）長谷川哲, 渡辺泰夫, 石田 稔, 他 : 大阪市中 央急病診療所における異物患者の現況.日気食 会報 35：438～441，1984.

7) 桑内隆郎, 西村忠郎, 高須昭彦, 他 : 当教室開 設時より 7 年間の食道及び気管・気管支異物の 統計的観察. 日気食会報 $32: 339 \sim 344,1981$.

8）大戸武久, 内田 豊, 遠藤朝彦, 他 : 当教室 10 年間の気管打よび食道異物の臨床統計観察. 日 気食会報 $32 ： 241 \sim 248,1981$.

9）森川美子, 瀧本 勲, 石神寛通, 他 : 当教室に おける異物症例の検討. 耳喉 $53: 1099 \sim 1105$, 1981.

10）西浦勇夫：開業 11 年間異物症例の統計。耳喉 $54: 471 \sim 477,1982$.

11）森本賢治，朝倉光司，砂金秀充，他：最近 10 年 間の食道および気管・気管支異物症例の統計的 観察. 耳展 $24: 139 \sim 144,1981$.

12）桶口彰宏, 鈴木 徹, 斎藤 彰, 他 : 開院以来 10 年間の気道食道異物の統計的観察. 日気食会報 $34: 255 \sim 259,1983$.
13）和田好弘, 芦沢泰博, 森 泰雄, 他: 当教室 7 年間の食道および気管・気管支異物の統計的観 察. 日気食会報 $37: 262 \sim 267,1986$.

14）小山 弘, 大川和春, 岡本康比古 : 当院気管食 道科に扣ける下気道・食道異物の臨床統計的観 察. 日気食会報 $37: 248 \sim 256,1986$.

15）松永 喬: 気道・食道異物の偶発性とその対策 一特に気道について．第38回日本気管食道学会 総会学術講演会. パネルディスカッション. 気 道・食道異物の偶発症とその対策 テキスト。 $6 \sim 17,1986$.

16）田中 治, 柏木令子, 松永喬, 他: X線透過 性下気道異物25症例の診断について。 日気食会 報 $36: 309 \sim 316,1985$.

17）金子省三, 日野原正, 秋山欣治, 他：小児気管 支異物の介在側について。日気食会報 $33: 31$ $\sim 36,1982$.

18）桶口晶子, 大石公直, 沢木修二：最近 5 年間の 興味ある食道異物症例. 日気食会報 $31 ： 444$ ·450, 1980.

19）松永 喬, 太田和博: 気道・食道異物症の予防. JOHNS $4:$ 1093 1100, 1988.

20）立木 孝, 斎藤達雄, 阿部 隆, 他: 胃に落下 した異物の転㷌について。聑喉 $53: 57 \sim 60$, 1981.

$$
\left(\begin{array}{l}
\text { 別刷請求先: 上田隆志 } \\
\text { 干634 槚原市四条町 } 840 \\
\text { 奈良県立医科大学耳鼻咽喉科学教室 }
\end{array}\right)
$$

